\title{
Management of Accredited Scientific Education Journals in State Islamic Universities
}

\section{Pengelolaan Jurnal Ilmiah Terakreditasi Bidang Ilmu Pendidikan di Perguruan Tinggi Islam Negeri}

Azkia Muharom Albantani \& Fatkhul Arifin

Universitas Islam Negeri Syarif Hidayatullah Jakarta

Paper Type:

Research Paper

\section{Abstract}

Background of the study: The paradigm shift in the management of scientific journals from print to electronic also has an impact on accreditation policies that were initially oriented towards print scientific periodicals to the accreditation of electronic-based scientific journals.

Purpose: This study aims to identify and explain the traditions and innovations in the management of accredited scientific education journals in PTKIN.

Method: This research is a qualitative research with the type of field research with the orientation of empirical data collection in the field. The researcher directly reviews the documents related to management, and observes the physical / nonphysical facilities used in the management of scientific journals.

Findings: The results showed that of the 9 (Nine) accredited education journals of PTKIN before 2018, the most widely cited is Dinamika Ilmu Journal, amounting to 251 (two hundred fifty one) times. This has happened because Dinamika Ilmu Journal has entered the age of 18 (eighteen) years. While the Edukasia Journal is the least quoted, which is 5 (five) times. Even though the age of Edukasia Journal enters the 13th (thirteenth) year.

Conclusion: From the 9 (nine) journals, only the Edukasia Journal still maintains to use the Indonesian full text even though it has been nationally accredited. While Edusains Journal, JPI Journal, Tarbiya Journal, and the Dinamika Ilmu Journal use English full text. This was done in order to support the vision of going international for his journals.

Keywords: accredited scientific journal, educational scientific journals, ptkin
Submitted: 10 January 2020 Online: 11 October 2020

* Correspondence: E-mail: azki@uinjkt.ac.id Azkia Muharom A. 
Abstrak

Latar belakang penelitian: Perubahan paradigma pengelolaan terbitan berkala ilmiah dari cetak menuju elektronik memberikan dampak kebijakan akreditasi yang mulanya berorientasi pada terbitan berkala ilmiah cetak menuju akreditasi terbitan berkala ilmiah berbasis elektronik.

Tujuan: Penelitian ini bertujuan untuk mengidentifikasi serta menjelaskan tradisi dan inovasi pengelolaan jurnal ilmiah terakreditasi bidang ilmu pendidikan di lingkungan PTKIN.

Metode: Penelitian ini merupakan penelitian kualitatif dengan jenis penelitian lapangan yang berorientasi pengumpulan data empiris lapangan. Peneliti secara langsung mengkaji dokumen-dokumen terkait pengelolaan, dan mengamati fasilitas fisik/nonfisik yang digunakan dalam pengelolaan jurnal ilmiah.

Temuan: Hasil penelitian menunjukkan bahwa dari 9 (Sembilan) Jurnal Bidang Ilmu Pendidikan di Lingkungan PTKIN yang terakreditasi sebelum tahun 2018, Jurnal Dinamika Ilmu paling banyak dikutip, yaitu sejumlah 251 (dua ratus lima puluh satu) kali. Hal ini sangat wajar, karena Jurnal Dinamika sudah memasuki usia ke 18 (delapan belas) tahun. Sedangkan, Jurnal Edukasia paling sedikit dikutip, yaitu sejumlah 5 (lima) kali. Padahal usia Jurnal Edukasia memasuki tahun ke 13 (tiga belas).

Kesimpulan: Dari ke 9 (sembilan) jurnal tersebut, hanya Jurnal Edukasia yang masih mempertahankan untuk menggunakan full text bahasa Indonesia, meski sudah terakreditasi nasional. Sedangkan, Jurnal Edusains, Jurnal JPI, Jurnal Tarbiya, dan Jurnal Dinamika Ilmu dengan mantap menggunakan full text bahasa Inggris. Hal tersebut dilakukan dalam rangka menunjang visi Go International untuk jurnaljurnalnya.

Kata kunci: jurnal ilmiah terakreditasi; jurnal ilmiah pendidikan; ptkin 


\section{Pendahuluan}

Perkembangan teknologi informasi dan komunikasi (TIK) pada era global ini, memberikan dampak perubahan paradigma kebijakan pengelolaan terbitan berkala ilmiah (TBI). Pada mulanya, pengelolaan TBI menggunakan kebijakan versi cetak, sedangkan saat ini paradigma tersebut sudah berpindah pada versi daring dengan istilah TBI elektronik (e-journal). Dengan demikian, pengelolaan TBI elektronik menjadi lebih cepat dari segi pengiriman (submit), penyuntingan (review), penelaahan (edit), dan penerbitan (publish) (Nashihuddin dan Aulianto, 2016).

Perubahan paradigma pengelolaan TBI dari cetak menuju elektronik memberikan dampak kebijakan akreditasi yang mulanya berorientasi pada TBI cetak menuju akreditasi TBI berbasis elektronik. Kemenristekdikti sebagai pemegang regulasi nasional terkait akreditasi TBI menyelaraskan kebijakan yang sudah ada dengan perkembangan perubahan paradigma pengelolaan TBI. Pada mulanya, akreditasi TBI diselenggarakan dengan menggunakan TBI versi cetak dengan jumlah eksemplar tidak sedikit, sedangkan saat ini penyelenggaraan akreditasi TBI dilakukan melalui laman akreditasi daring dengan nama Arjuna yang merupakan singkatan dari Akreditasi Jurnal Nasional (Ditlitabmas, 2014).

Dalam rangka meningkatkan mutu suatu jurnal yang belum terakreditasi menuju jurnal yang terakreditasi secara nasional maupun internasional, maka diperlukan dukungan dari berbagai hal untuk dapat merealisasikan tujuan tersebut. Jurnal ilmiah harus dipersiapkan untuk menuju Jurnal yang terakreditasi Nasional dan dapat terindex Scopus (Rosyada, 2015).

Hal ini seiring dengan tuntutan dari profesi seorang Dosen/Guru yang dalam tugasnya tidak hanya mengajar mahasiswa/siswa, akan tetapi, juga diharapkan dapat melakukan penelitian yang dipublikasikan di jurnal-jurnal ilmiah serta melakukan pengabdian kepada masyarakat. Selain itu tuntutan dari Lembaga Pendidikan untuk para mahasiswa program magister dan program doktor yang mewajibkan mahasiswanya untuk mempublikasikan hasil penelitiannya ke jurnal-jurnal ilmiah (Hariyanto, 2016).

Pada prosesnya artikel yang masuk harus melewati review dari para Mitra Bestari (penyunting ahli) profesional, baik berasal dari dalam maupun luar negeri, sehingga membutuhkan waktu yang agak lama, hal itu dilakukan untuk menjamin tulisan yang dimuat merupakan tulisan-tulisan yang berkualitas dan bermanfaat untuk pengembangan ilmu dari para pembaca.

Apalagi ditunjang dengan tuntutan Beban Kinerja Dosen (BKD) yang mengharuskan dosen untuk bisa mempublikasikan tulisan-tulisannya di jurnal-jurnal ilmiah yang ada. Hal ini, merupakan peluang yang sangat besar bagi jurnal ilmiah untuk bisa mempublikasikan karya-karya dari hasil penelitian maupun kajian mendalam di bidang keahlian mereka. Maka, kebutuhan untuk keberlangsungan penerbitan jurnal ilmiah dan peningkatan kualitasnya menjadi jurnal terakreditasi dan terindeks Scopus menjadi sebuah kebutuhan yang sangat penting, baik untuk keperluan para penulis maupun untuk lembaga PTKIN.

Saat ini, dosen dengan jabatan fungsional Lektor Kepala memiliki kewajiban per 3 (tiga) tahun untuk menerbitkan minimal 3 (tiga) artikel ilmiah dalam terbitan berkala ilmiah nasional terakreditasi atau 1 (satu) artikel ilmiah dalam terbitan berkala ilmiah internasional. Sedangkan dosen dengan jabatan fungsional guru besar memiliki kewajiban per 3 tahun untuk menerbitkan minimal 3 (tiga) artikel ilmiah dalam terbitan berkala ilmiah internasional atau 1 (satu) artikel ilmiah dalam terbitan berkala ilmiah internasional bereputasi seperti terindeks Scopus atau Clarivate (Permenristekdikti Nomor 20 Tahun 2017). Dengan demikian, perlu adanya dukungan bantuan dana akselerasi akreditasi jurnal yang dapat memberikan penguatan program-program yang ditujukan untuk meningkatkan status jurnal dari yang belum terakreditasi menjadi jurnal yang terakreditasi Nasional dan terindeks di Scopus.

Saat ini, Kemenristekdikti telah memperkenalkan aplikasi science and technology index dengan sebutan SINTA. Aplikasi ini memiliki 5 (lima) fungsi di antaranya; a) menjadi bank data publikasi dan sitasi akademisi dan peneliti dengan lingkup Indonesia; b) menjadi instrumen penilaian kinerja jurnal berdasarkan standar akreditasi dan sitasi; c) menjadi intrumen analisis profil institusi, penulis, dan jurnal; d) menjadi intrumen pemeringkatan institusi, penulis, dan jurnal; e) menjadi instrumen penilaian kinerja publikasi dosen dan peneliti (Kemenristekdikti, 2017).

To cite this document:

Albantani, A. M., \& Arifin, F. (2020), Management of Accredited Scientific Education Journals in State

Islamic Universities. Record and Library Journal, 6(2), 154-165.

Open access under Creative Commons Attribution-Non Commercial-Share A like 4.0 International Licence

(CC-BY-SA) 
Dengan aplikasi SINTA, jurnal ilmiah dikategorisasikan ke dalam 6 (enam) kriteria, yaitu SINTA Peringkat 1 (terakreditasi A atau terindeks global); SINTA Peringkat 2 (terakreditasi B); SINTA Peringkat 3 (skor 60-70); SINTA Peringkat 4 (skor 50-60); SINTA Peringkat 5 (skor 40-50); dan SINTA Peringkat 6 (skor 30-40). Selain itu, Kemenristekdikti juga mulai mengadakan SINTA Award untuk memberikan penghargaan kepada jurnal ilmiah terproduktif di SINTA yang memiliki kriteria skor tertinggi dengan memperhitungkan jumlah sitasi. Hal tersebut, dapat meningkatkan motivasi peningkatan kualitas dalam pengelolaan jurnal ilmiah.

Fakultas Tarbiyah merupakan fakultas terfavorit di lingkungan PTKIN se-Indonesia. Hal ini, dibuktikan dengan jumlah mahasiswa Fakultas Tarbiyah di lingkungan PTKIN yang menjadi mayoritas di setiap tahunnya. Hal tersebut, menunjukkan bahwa jumlah dosen pada fakultas tersebut tidak sedikit. Dengan demikian, kebutuhan jurnal ilmiah bidang ilmu pendidikan merupakan hal yang patut dipenuhi dalam jangka pendek dan panjang. Pada tahun 2017, data Kemenristekdikti menunjukkan bahwa jumlah kekurangan dari kebutuhan jurnal nasional terakreditasi bidang ilmu pendidikan mencapai 1.953 jurnal (Kemenristekdikti, 2017). Di saat yang sama, jurnal ilmiah elektronik di Indonesia telah mencapai 21.820 jurnal.

Di sisi lain, penelitian Hariyah (2016) menunjukkan bahwa sepanjang 2004-2014, tema pendidikan khususnya pendidikan Islam merupakan tema yang paling dominan dipublikasikan pada jurnal-jurnal di lingkungan PTKIN. Dengan demikian, PTKIN sudah seharusnya memiliki jurnal kajian pendidikan terakreditasi untuk mewadahi dominasi artikel dengan tema pendidikan. Hal ini, didukung oleh penelitian Kusuma (2016) yang menunjukkan bahwa, kampus perlu menyediakan layanan sumber data dan informasi dalam hal ini, jurnal ilmiah yang dapat menunjang mahasiswa untuk menulis. Sebagaimana penelitian Ansor (2017) menunjukkan bahwa, jurnal elektronik banyak dimanfaatkan oleh mahasiswa dalam rangka publikasi ilmiah bereputasi internasional.

Dengan berbagai fakta tersebut, hal yang paling memilukan adalah jurnal ilmiah bidang ilmu pendidikan yang dimiliki oleh PTKIN se-Indonesia hanya berjumlah 9 (sembilan) jurnal, yaitu Jurnal Tarbiya (UIN Jakarta), Jurnal Arabiyat (UIN Jakarta), Jurnal Edusains (UIN Jakarta), Jurnal Nadwa (UIN Semarang), Jurnal Al-Ta'lim (UIN Padang), Jurnal Pendidikan Islam (UIN Bandung), Jurnal Pendidikan Islam (UIN Yogyakarta), Jurnal Edukasia (STAIN Kudus), dan Jurnal Dinamika Ilmu (IAIN Samarinda). Dengan demikian, hal tersebut merupakan pekerjaan rumah yang perlu dibenahi secara sinergi antara PTKIN dan Kementerian Agama. Selain itu, jurnal ilmiah bidang ilmu pendidikan lainnya dapat belajar banyak dari kesuksesan jurnal ilmiah lainnya yang telah terakreditasi terlebih dahulu.

Rumusan permasalahan yang hendak dikaji dalam tulisan ini di antaranya: "bagaimana tradisi dan inovasi pengelolaan jurnal ilmiah terakreditasi bidang ilmu pendidikan di lingkungan PTKIN, meliputi Jurnal Tarbiya (UIN Jakarta), Jurnal Arabiyat (UIN Jakarta), Jurnal Edusains (UIN Jakarta), Jurnal Nadwa (UIN Semarang), Jurnal Al-Ta'lim (UIN Padang), Jurnal Pendidikan Islam (UIN SGD Bandung), Jurnal Pendidikan Islam (UIN SUKA Yogyakarta), Jurnal Edukasia (STAIN Kudus), dan Jurnal Dinamika Ilmu (IAIN Samarinda)?"

Penelitian ini bertujuan untuk mengidentifikasi dan menjelaskan tradisi dan inovasi pengelolaan jurnal ilmiah terakreditasi bidang ilmu pendidikan di lingkungan PTKIN, meliputi Jurnal Tarbiya (UIN Jakarta), Jurnal Arabiyat (UIN Jakarta), Jurnal Edusains (UIN Jakarta), Jurnal Nadwa (UIN Semarang), Jurnal Al-Ta'lim (UIN Padang), Jurnal Pendidikan Islam (UIN SGD Bandung), Jurnal Pendidikan Islam (UIN SUKA Yogyakarta), Jurnal Edukasia (STAIN Kudus), dan Jurnal Dinamika Ilmu (IAIN Samarinda).

Penelitian ini ditujukan untuk program pengembangan Jurnal Ilmiah di lingkungan FITK UIN Syarif Hidayatullah Jakarta yang dipersiapkan untuk menjadi jurnal yang terakreditasi Nasional dan terindeks di Scopus, untuk itu banyak hal yang harus dipersiapkan, baik dari segi materiil maupun non materiil. Seperti, peningkatan jumlah dan kemampuan dari pengelolanya.

Hasil penelitian diharapkan dapat memberikan kontribusi ilmiah dalam proses pengembangan mutu dan kualitas pengelolaan jurnal ilmiah bidang ilmu pendidikan di lingkungan PTKIN menuju terakreditasi nasional dan memperoleh pengakuan internasional (terindeks Scopus). Beberapa sasaran

To cite this document:

Albantani, A. M., \& Arifin, F. (2020), Management of Accredited Scientific Education Journals in State

Islamic Universities. Record and Library Journal, 6(2), 154-165.

Open access under Creative Commons Attribution-Non Commercial-Share A like 4.0 International Licence

(CC-BY-SA) 
pengajuan bantuan penelitian ini adalah meningkatnya kompetensi SDM pengelola jurnal ilmiah, meningkatnya mutu jurnal ilmiah, dan SDM di antaranya para dosen se-Indonesia, para mahasiswa Program Magister, dan Doktor konsentrasi bidang ilmu pendidikan.

\section{'Metode Penelitian}

Penelitian ini menggunakan jenis penelitian kualitatif (Creswell, 1998) dengan orientasi pengumpulan data empiris lapangan (Donim, 2002). Peneliti secara langsung menganilisis dokumendokumen yang berkaitan dengan pengelolaan dan mengamati fasilitas fisik/nonfisik yang digunakan dalam pengelolaan jurnal ilmiah (Rahmat, 2009). Penelitian ini juga menggunakan pendekatan penelitian kepustakaan (library research) dengan meneliti bahan-bahan kepustakaan yang berkaitan dengan pengelolaan jurnal ilmiah terakreditasi (Nazir, 1999). Pendekatan ini dilakukan dengan cara mengumpulkan data maupun informasi dari berbagai sumber kepustakaan (Marzuki, 2005). Berbagai data dan informasi yang merupakan temuan penelitian tidak hanya dideskripsikan, tetapi juga dianalis dan ditafsirkan sesuai dengan makna data tersebut. Setelah itu, peneliti mengomentari dan memberikan masukan terhadap pengelolaan jurnal ilmiah terakreditasi. Dengan demikian, penelitian ini juga merupakan penelitian deskriptif analisis kritis (Sya'ban, 2005). Di sisi lain, pendekatan evaluatif juga digunakan dalam penelitian ini untuk memberikan rekomendasi akhir yang menyatakan bahwa suatu objek evaluasi dapat dipertahankan, ditingkatkan, diperbaiki atau bahkan dihentikan sejalan dengan data yang diperoleh tentang pengelolaan jurnal ilmiah terakreditasi bidang ilmu pendidikan (Arikunto, 2010).

Ruang lingkup penelitian ini dibatasi jurnal ilmiah terakreditasi bidang ilmu pendidikan di lingkungan PTKIN, meliputi Jurnal Pendidikan Islam (UIN SGD Bandung), Jurnal Pendidikan Islam (UIN SUKA Yogyakarta), Edukasia : Jurnal Penelitian Pendidikan Islam (STAIN Kudus), dan Dinamika Ilmu (IAIN Samarinda). Keempat jurnal tersebut telah terakreditasi B oleh Kemenristekdikti. Dengan demikian, jurnal-jurnal tersebut harus menjadi permodelan untuk pengelolaan jurnal lainnya. Hal tersebut, dalam rangka menjadikan penelitian lebih berfokus untuk merekonstruksi pengelolaan jurnal ilmiah di lingkungan FITK UIN Jakarta yang sesuai dengan arah perkembangan kebijakan nasional. Jurnal yang diteliti adalah jurnal yang sudah diakreditasi sebelum diterbitkannya Permenristekdikti Nomor 9 Tahun 2018.

Teknik wawancara (in-depth interview) (Prastowo, 2012; Arikunto, 2006) digunakan sebagai teknik utama untuk menggali secara mendalam informasi tentang pengelolaan jurnal ilmiah terakreditasi. Adapun yang menjadi objek wawancara, meliputi dewan redaksi jurnal ilmiah terakreditasi bidang ilmu pendidikan di lingkungan PTKIN yang menjadi sasaran penelitian. Instrumen wawancara yang digunakan dalam penelitian ini merupakan pengembangan dari instrumen evaluasi diri pengelolaan jurnal (manajerial dan substansi) berdasarkan Peraturan Direktur Jenderal Pendidikan Tinggi (Dirjen Dikti) Kemdikbud RI Nomor 1 tahun 2014. Studi dokumentasi juga dilakukan untuk melacak data dan informasi penunjang penelitian. Adapun dokumen yang akan dikaji oleh peneliti, meliputi: 1) kebijakan kampus; 2) materi OJS; 3) naskah artikel.

Uji triangulasi juga digunakan dalam penelitian ini untuk menguji validitas dan reliabilitas data, meliputi uji referensi (kepustakaan), uji member check kepada objek penelitian, dan konsultasi dengan para ahli terkait penelitian. Teknik analisis data yang digunakan dalam penelitian ini meliputi: a) Pengumpulan data terkait penelitian; b) Reduksi data untuk memilih hal-hal pokok terkait fokus penelitian; c) Penyajian data meliputi proses klasifikasi data untuk memudahkan analisis dan penyimpulan data (Meleong, 2002); serta d) Verifikasi data untuk penarikan kesimpulan yang diperkuat dengan bukti-bukti dari data-data yang telah dikumpulkan.

Metode analisis data induktif juga digunakan dalam penelitian ini dalam rangka memahami data dan informasi yang diperoleh dari lapangan, kemudian disintesiskan ke dalam beberapa kategori sesuai dengan beberapa teori yang relevan (Anggoro, 2007).

To cite this document:

Albantani, A. M., \& Arifin, F. (2020), Management of Accredited Scientific Education Journals in State

Islamic Universities. Record and Library Journal, 6(2), 154-165.

Open access under Creative Commons Attribution-Non Commercial-Share A like 4.0 International Licence

(CC-BY-SA) 


\section{Hasil dan Diskusi}

Jurnal merupakan bagian dari jenis terbitan berkala yang ada di perpustakaan, adapun istilah jurnal menurut High Beam, "Journal is the collection and periodic publication or transmission of news and the result of research through media," artinya jurnal merupakan suatu koleksi dan terbitan berkala atau transmisi mengenai berita dan hasil-hasil penelitian mengenai media.

Dari 9 (Sembilan) Jurnal Bidang Ilmu Pendidikan di Lingkungan PTKIN yang terakreditasi sebelum tahun 2018, data menunjukkan bahwa hanya Jurnal Edusains (UIN Jakarta) yang memiliki ruang lingkup kajian pendidikan ilmu pengetahuan alam dan hanya Jurnal Arabiyat (UIN Jakarta) yang memiliki ruang lingkup kajian kebahasaaraban. Sedangkan ke 7 (tujuh) jurnal lainnya memiliki ruang lingkup sangat luas, meliputi kajian pendidikan Islam ditinjau dari berbagai aspek.

Dari segi usia pengelolaan jurnal, Jurnal Al-Ta'lim (UIN Padang) memiliki usia yang dapat dikatakan paling senior. Pada 2018, Jurnal Al-Ta'lim memasuki usia ke 25 (dua puluh lima) tahun penerbitan. Sedangkan Jurnal Tarbiya dan Arabiyat (UIN Jakarta) memiliki usia penerbitan yang dapat dikatakan paling junior. Pada 2018, kedua jurnal tersebut baru memasuki usia ke 5 (lima) tahun penerbitan. Namun demikian, meski usia kedua jurnal tersebut terbilang muda, keseriusan pengelolaan kedua jurnal tersebut dapat mengantarkan Jurnal Tarbiya dan Arab memperoleh Akreditasi "B" di akhir tahun 2017 bertepatan dengan usia ke 3 (tiga) tahun penerbitan.

Tabel 1. Awal Tahun Terbit

\begin{tabular}{lll}
\hline No & Nama Jurnal & Awal Terbit \\
\hline $\mathbf{1}$ & Jurnal Al-Ta'lim (UIN Padang) & 1994 \\
$\mathbf{2}$ & Jurnal Edukasia (STAIN Kudus) & 2006 \\
$\mathbf{3}$ & Jurnal Nadwa (UIN Walisongo) & 2007 \\
$\mathbf{4}$ & JPI (UIN Bandung) & 2008 \\
$\mathbf{5}$ & Jurnal Edusains (UIN Jakarta) & 2009 \\
$\mathbf{6}$ & Jurnal Dinamika Ilmu (IAIN Samarinda) & 2011 \\
$\mathbf{7}$ & JPI (UIN Yogyakarta) & 2012 \\
$\mathbf{8}$ & Jurnal Tarbiya (UIN Jakarta) & 2014 \\
$\mathbf{9}$ & Jurnal Arabiyat (UIN Jakarta) & 2014 \\
\hline
\end{tabular}

Dari segi versi OJS, pengelola ke 9 (sembilan) jurnal pendidikan di lingkungan PTKIN sepakat untuk menggunakan OJS versi 2.4 bukan versi 3.0 dan seterusnya. Hal ini, memiliki alasan yang sangat kuat. Pengelolaan jurnal ilmiah secara daring menggunakan OJS versi 2.4 lebih memberikan kemudahan bagi pengelola jurnal. Sedangkan, penggunaan OJS versi 3.0 malah sebaliknya memberikan banyak pekerjaan rumah baru bagi pengelola jurnal, misalnya peran (role) yang terdapat di versi ini terlalu banyak. Namun, tidak sedikit para pengelola jurnal yang menyiasati hal tersebut dengan membuat OJS versi 2.4 rasa OJS versi 3.0 melalui modifikasi penggunaan tema (theme). Nyatanya tampilan OJS versi 3.0 sangat diminati mayoritas pengelola jurnal, namun tidak untuk pengelolaan datanya.

Dari segi kualitas mitra bebestari, nyatanya kepemilikin Scopus ID masih menjadi primadona dan daya tarik tersendiri bagi pengelola jurnal. Namun, hal ini bukannya tidak beralasan, akan tetapi kebijakan nasional juga yang menuntut kita untuk cenderung seperti itu. Menurut kebijakan nasional, Indeks Scopus dan Thomson masih menjadi ukuran kualitas tertinggi pengelolaan sebuah jurnal ilmiah. Dengan demikian, ke 9 (sembilan) jurnal pendidikan di lingkungan PTKIN sudah mulai menyiapkan diri menuju ke arah sana.

Dari segi bahasa Abstrak, ke 9 (sembilan) jurnal sudah menyediakan abstrak berbahasa Inggris. Meskipun beberapa jurnal masih menyediakan full text berbahasa Indonesia, namun seluruh abstrak tersedia dalam bahasa Inggris. Ketersediaan abstrak dalam bahasa Inggris pun memiliki poin lebih besar dalam penilaian akreditasi jurnal ilmiah nasional. Dengan demikian, keseluruhan 9 (sembilan) jurnal tersebut sudah memiliki tingkat keterbacaan yang luas dengan tersedianya abstrak berbahasa Inggris.

To cite this document:

Albantani, A. M., \& Arifin, F. (2020), Management of Accredited Scientific Education Journals in State

Islamic Universities. Record and Library Journal, 6(2), 154-165.

Open access under Creative Commons Attribution-Non Commercial-Share A like 4.0 International Licence

(CC-BY-SA) 
Tabel 2. Data Bahasa Abstrak

\begin{tabular}{lll}
\hline No & Nama Jurnal & Bahasa Abstrak \\
\hline $\mathbf{1}$ & JPI (UIN Bandung) & Inggris \\
$\mathbf{2}$ & Jurnal Edusains (UIN Jakarta) & Inggris dan Indonesia \\
$\mathbf{3}$ & Jurnal Nadwa (UIN Walisongo) & Inggris dan Indonesia \\
$\mathbf{4}$ & Jurnal Al-Ta'lim (UIN Padang) & Inggris \\
$\mathbf{5}$ & JPI (UIN Yogyakarta) & Inggris dan Indonesia \\
$\mathbf{6}$ & Jurnal Tarbiya (UIN Jakarta) & Inggris dan Indonesia \\
$\mathbf{7}$ & Jurnal Edukasia (STAIN Kudus) & Inggris dan Indonesia \\
$\mathbf{8}$ & Jurnal Arabiyat (UIN Jakarta) & Inggris dan Indonesia \\
$\mathbf{9}$ & Jurnal Dinamika Ilmu (IAIN Samarinda) & Inggris \\
\hline
\end{tabular}

Dari segi gaya kutipan dan daftar rujukan, 5 (lima) jurnal menggunakan gaya kutipan dan daftar rujukan model APA Style (bodynote) dan 4 (empat) jurnal menggunakan gaya kutipan dan daftar rujukan model Turabiyan Style (Footnote). Penggunaan gaya APA Style sebetulnya mengurangi pekerjaan rumah pengelola jurnal. Jika pengelola menggunakan Turabiyan Style, maka pengelola mendapatkan tugas tambahan untuk mengecek kesesuaian penulisan catatan kaki. Namun, hal tersebut bisa dihindari apabila semua penulis menggunakan aplikasi manajemen referensi. Nyatanya, anjuran penggunaan aplikasi ini masih agak kesulitan diterapkan oleh keseluruhan penulis yang tidak peka terhadap teknologi kekinian yang berkembang.

Tabel 3. Data Gaya Kutipan

\begin{tabular}{lll}
\hline No & Nama Jurnal & Gaya Kutipan \\
\hline $\mathbf{1}$ & JPI (UIN Bandung) & Turabiyan Style \\
$\mathbf{2}$ & Jurnal Edusains (UIN Jakarta) & APA Style \\
$\mathbf{3}$ & Jurnal Nadwa (UIN Walisongo) & Turabiyan Style \\
$\mathbf{4}$ & Jurnal Al-Ta'lim (UIN Padang) & APA Style \\
$\mathbf{5}$ & JPI (UIN Yogyakarta) & Turabiyan Style \\
$\mathbf{6}$ & Jurnal Tarbiya (UIN Jakarta) & APA Style \\
$\mathbf{7}$ & Jurnal Edukasia (STAIN Kudus) & APA Style \\
$\mathbf{8}$ & Jurnal Arabiyat (UIN Jakarta) & Turabiyan Style \\
$\mathbf{9}$ & Jurnal Dinamika Ilmu (IAIN Samarinda) & APA Style \\
\hline
\end{tabular}

Dari segi pencegahan tindak plagiasi, ke 9 (sembilan) jurnal pendidikan di lingkungan PTKIN sudah sepakat melakukan hal tersebut ditandai dengan tersedianya informasi pencegahan tindak plagiasi di laman OJS. Namun demikian, kepemilikan akses aplikasi daring plagiarism checker belum dimiliki oleh keseluruhan jurnal tersebut. Saat ini, baru 3 (tiga) jurnal yang dapat menggunakan aplikasi daring plagiarism checker, yaitu Turnitin dalam mencegah terjadinya tindak plagiasi. Ketiga jurnal tersebut diterbitkan oleh UIN Jakarta yang telah melanggan Turnitin secara tahunan. Ketiga jurnal tersebut meliputi Jurnal Tarbiya, Jurnal Arabiyat, dan Jurnal Edusains.

Dari segi nomor unik artikel, ke 9 (sembilan) jurnal pendidikan di lingkungan PTKIN sudah sepakat untuk menggunakan DOI (Digital Object Identifier) yang disediakan oleh Crossref. Kepemilikan DOI nyatanya menjadi salah satu poin penilaian dalam proses akreditasi jurnal secara daring. Lebih dari itu, kepemilikan DOI juga memiliki banyak manfaat bagi jurnal dan bahkan para penulis artikelnya. Manfaat bagi jurnal, kepemilikan DOI sangat membantu dalam proses penambahan lembaga indeksasi, seperti DOAJ dan Dimensions. Sedangkan manfaat bagi penulis, kepemilikan DOI dapat membantu tulisannya agar masuk ke dalam list publikasi di laman OrchID. Setiap artikel yang memiliki DOI pun sangat membantu calon penulis artikel jurnal dalam mengutip artikel-artikel jurnal menggunakan aplikasi manajemen referensi, seperti ZOTERO. Calon penulis cukup menyematkan DOI artikel yang akan dikutip pada aplikasi ZOTERO. Setelah itu, informasi lengkap terkait artikel segera muncul untuk masuk dalam informasi kutipan atau daftar rujukan.

Dari segi ukuran kertas, 5 (lima) jurnal memilihs ukuran B5. Sedang 4 (empat) jurnal lainnya memilih ukuran A4. Kedua pilihan tersebut memiliki masing-masing alasan kuat. Ukuran A4 memiliki 
nilai lebih tinggi dibanding ukuran B5 menurut informasi yang tertuang di dalam pedoman akreditasi jurnal nasional secara daring. Sedangkan ukuran B5 mayoritas dipilih oleh pengelola jurnal dengan alasan supaya versi cetaknya lebih nyaman dibawa dan dibaca. Ukuran A4 dalam versi cetak sangat kurang nyaman untuk dibawa secara mobile.

Tabel 4. Ukuran Kertas

\begin{tabular}{lll}
\hline No & Nama Jurnal & Ukuran Kertas \\
\hline $\mathbf{1}$ & Jurnal Al-Ta'lim (UIN Padang) & A4 \\
$\mathbf{2}$ & Jurnal Edukasia (STAIN Kudus) & B5 \\
$\mathbf{3}$ & Jurnal Nadwa (UIN Walisongo) & B5 \\
$\mathbf{4}$ & JPI (UIN Bandung) & B5 \\
$\mathbf{5}$ & Jurnal Edusains (UIN Jakarta) & A4 \\
$\mathbf{6}$ & Jurnal Dinamika Ilmu (IAIN Samarinda) & B5 \\
$\mathbf{7}$ & JPI (UIN Yogyakarta) & A4 \\
$\mathbf{8}$ & Jurnal Tarbiya (UIN Jakarta) & A4 \\
$\mathbf{9}$ & Jurnal Arabiyat (UIN Jakarta) & B5 \\
\hline
\end{tabular}

Jurnal Dinamika Ilmu, paling banyak dikutip, yaitu sejumlah 251 (dua ratus lima puluh satu) kali. Hal ini, sangat wajar karena Dinamika sudah memasuki usia ke 18 (delapan belas) tahun. Sedangkan Jurnal Edukasia paling sedikit dikutip, yaitu sejumlah 5 (lima) kali. Padahal usia Edukasia memasuki tahun ke 13 (tiga belas).

\begin{tabular}{|c|c|c|c|c|}
\hline No & Nama Jurnal & $\begin{array}{l}\text { Jumlah } \\
\text { Kutipan }\end{array}$ & $\begin{array}{l}\text { h- } \\
\text { index }\end{array}$ & $\begin{array}{l}\text { i10- } \\
\text { index }\end{array}$ \\
\hline 1 & Jurnal Dinamika Ilmu (IAIN Samarinda) & 251 & 8 & 5 \\
\hline 2 & JPI (UIN Yogyakarta) & 246 & 8 & 7 \\
\hline 3 & Jurnal Al-Ta'lim (UIN Padang) & 175 & 7 & 4 \\
\hline 4 & Jurnal Edusains (UIN Jakarta) & 129 & 6 & 2 \\
\hline 5 & JPI (UIN Bandung) & 105 & 4 & 1 \\
\hline 6 & Jurnal Arabiyat (UIN Jakarta) & 87 & 5 & 1 \\
\hline 7 & Jurnal Nadwa (UIN Walisongo) & 83 & 5 & 1 \\
\hline 8 & Jurnal Tarbiya (UIN Jakarta) & 25 & 2 & 0 \\
\hline 9 & Jurnal Edukasia (STAIN Kudus) & 5 & 2 & 0 \\
\hline
\end{tabular}

Dari segi jumlah halaman, Jurnal Edukasia (STAIN Kudus) memiliki jumlah halaman terbanyak untuk setiap jilidnya (2 edisi), yang mencapai 500 halaman. Hal tersebut, sangatlah wajar mengingat jurnal tersebut merupakan jurnal ilmiah kajian ilmu sosial. Sedangkan Jurnal Edusains dan Tarbiya (UIN Jakarta) memiliki jumlah halaman tersedikit untuk setiap jilidnya, yang mencapai 230 halaman. Jumlah halaman tersebut sangatlah wajar bagi Jurnal Edusains yang memiliki kajian ilmu sains. Namun, sangat disayangkan apabila Jurnal Tarbiya yang memiliki kajian ilmu sosial hanya memiliki ketebalan kurang dari 300 halaman untuk setiap jilidnya (2 edisi).

Tabel 6. Data Jumlah Halaman per Volume

\begin{tabular}{lll}
\hline No & Nama Jurnal & Halaman per Volume \\
\hline $\mathbf{1}$ & Jurnal Al-Ta'lim (UIN Padang) & $270 \mathrm{an}$ \\
$\mathbf{2}$ & Jurnal Edukasia (STAIN Kudus) & $500 \mathrm{an}$ \\
$\mathbf{3}$ & Jurnal Nadwa (UIN Walisongo) & $290 \mathrm{an}$ \\
$\mathbf{4}$ & JPI (UIN Bandung) & $300 \mathrm{an}$ \\
$\mathbf{5}$ & Jurnal Edusains (UIN Jakarta) & $230 \mathrm{an}$ \\
$\mathbf{6}$ & Jurnal Dinamika Ilmu (IAIN Samarinda) & $330 \mathrm{an}$ \\
$\mathbf{7}$ & JPI (UIN Yogyakarta) & $490 \mathrm{an}$ \\
\hline
\end{tabular}

To cite this document:

Albantani, A. M., \& Arifin, F. (2020), Management of Accredited Scientific Education Journals in State

Islamic Universities. Record and Library Journal, 6(2), 154-165.

Open access under Creative Commons Attribution-Non Commercial-Share A like 4.0 International Licence

(CC-BY-SA) 


\begin{tabular}{lll}
\hline 8 & Jurnal Tarbiya (UIN Jakarta) & 230 an \\
9 & Jurnal Arabiyat (UIN Jakarta) & 320 an \\
\hline
\end{tabular}

Dari segi resolusi pdf, ke 9 (sembilan) jurnal menyajikan artikel dalam bentuk file pdf dengan resolusi tinggi namun dengan ukuran file tidak terlalu besar. Dengan demikian, para pembaca diberikan kemudahan untuk membaca artikel secara daring.

Selain itu, dari ke 9 (sembilan) jurnal tersebut, hanya Jurnal Edukasia yang masih mempertahankan untuk menggunakan full text bahasa Indonesia meski sudah terakreditasi nasional. Sedangkan Jurnal Edusains, Jurnal JPI, Jurnal Tarbiya, dan Jurnal Dinamika Ilmu dengan mantap menggunakan full text bahasa Inggris. Hal tersebut, dilakukan dalam rangka menunjang visi go international untuk jurnaljurnalnya.

Tabel 7. Data Bahasa Full text

\begin{tabular}{lll}
\hline No & Nama Jurnal & Bahasa Fulltext \\
\hline $\mathbf{1}$ & JPI (UIN Bandung) & Arab dan Inggris \\
$\mathbf{2}$ & Jurnal Edusains (UIN Jakarta) & Inggris \\
$\mathbf{3}$ & Jurnal Nadwa (UIN Walisongo) & Inggris dan Indonesia \\
$\mathbf{4}$ & Jurnal Al-Ta'lim (UIN Padang) & Arab dan Inggris \\
$\mathbf{5}$ & JPI (UIN Yogyakarta) & Inggris \\
$\mathbf{6}$ & Jurnal Tarbiya (UIN Jakarta) & Inggris \\
$\mathbf{7}$ & Jurnal Edukasia (STAIN Kudus) & Indonesia \\
$\mathbf{8}$ & Jurnal Arabiyat (UIN Jakarta) & Arab dan Indonesia \\
$\mathbf{9}$ & Jurnal Dinamika Ilmu (IAIN Samarinda) & Inggris \\
\hline
\end{tabular}

Dari segi diversifikasi penulis, hanya 4 (empat) jurnal yang memiliki ketersebaran penulis hingga luar negeri. Namun uniknya, terdapat 1 (satu) jurnal yang memiliki ketersebaran penulis hanya lingkup dalam negeri, yaitu Jurnal Edukasia (STAIN Kudus). Hal ini, dibuktikan dengan ketersediaan full text hanya dalam bahasa Indonesia. Namun demikian, hal tersebut bisa menunjukkan bahwa jurnal tersebut menantang penulis luar negeri untuk dapat mempublikasikan artikel ilmiahnya ke dalam bahasa Indonesia. Hal tersebut, sesuai dengan istilah perumpamaan Think Globally Act Locally.

JPI (UIN Bandung), Jurnal Al-Talim (UIN Padang), Jurnal Tarbiya (UIN Jakarta), dan Jurnal Arabiyat (UIN Jakarta) memiliki ketersebaran penulis hingga ke beberapa negara. JPI (UIN Bandung) memiliki penulis luar yang berasal dari 8 (delapan) negara, disusul dengan Jurnal Arabiyat dan Tarbiya (UIN Jakarta) yang memiliki penulis luar yang berasal dari 7 (tujuh) negara. Lalu Jurnal Al-Ta'lim (UIN Padang yang memiliki penulis luar yang berasal dari 2 (dua) negara.

Tabel 8. Data Sebaran Asal Penulis Luar Negeri

\begin{tabular}{lll}
\hline No & Nama Jurnal & $\begin{array}{l}\text { Asal Penulis } \\
\text { Luar Negeri }\end{array}$ \\
\hline $\mathbf{1}$ & JPI (UIN Bandung) & Amerika Serikat \\
& & Arab Saudi \\
& & Brunei Darussalam \\
& & Israel \\
& & Kanada \\
& & Malaysia \\
& & Nigeria \\
& & Perancis \\
$\mathbf{2}$ & Jurnal Edusains (UIN Jakarta) & \\
$\mathbf{3}$ & Jurnal Nadwa (UIN Walisongo) & Australia \\
$\mathbf{4}$ & Jurnal Al-Ta'lim (UIN Padang) & Malaysia \\
& & \\
$\mathbf{5}$ & JPI (UIN Yogyakarta) & Australia \\
$\mathbf{6}$ & Jurnal Tarbiya (UIN Jakarta) & \\
\hline
\end{tabular}

To cite this document:

Albantani, A. M., \& Arifin, F. (2020), Management of Accredited Scientific Education Journals in State

Islamic Universities. Record and Library Journal, 6(2), 154-165.

Open access under Creative Commons Attribution-Non Commercial-Share A like 4.0 International Licence 


\begin{tabular}{lll}
\hline & Jepang \\
& Kanada & Kazakhstan \\
& Kyrgyztan \\
& Malaysia \\
& Nigeria \\
& & \\
$\mathbf{8} \quad$ Jurnal Edukasia (STAIN Kudus) & Arab Saudi \\
& & Brunei Darussalam \\
& & Jerman \\
& & Jordan \\
& Malaysia \\
& Jurnal Dinamika Ilmu (IAIN Samarinda) & Suriah \\
& & Viet Nam \\
\hline
\end{tabular}

Dari segi kunjungan unik, Jurnal al-Ta'lim (UIN Padang) memiliki jumlah kunjungan unik terbanyak, yaitu mencapai 85 kunjungan unik per minggu. Jumlah kunjungan tersebut sangatlah wajar karena kesembilan jurnal sudah berstatus terakreditasi nasional. Namun, sangat disayangkan pada Jurnal Pendidikan Islam (UIN Yogyakarta) yang belum disematkan aplikasi state counter di dalam sistem OJS, sehingga belum bisa dinilai tingkat eksistensi kunjungan pembaca yang membutuhkan tulisan ilmiah mengenai kajian pendidikan Islam.

\begin{tabular}{lll}
\multicolumn{2}{l}{ Tabel 9. Data Kunjungan Unik (diakses 9} & Oktober 2018 dari http://statcounter.com) \\
\hline No & Nama Jurnal & Kunjungan Unik \\
\hline $\mathbf{1}$ & JPI (UIN Bandung) & 21 per minggu \\
$\mathbf{2}$ & Jurnal Edusains (UIN Jakarta) & 81 per minggu \\
$\mathbf{3}$ & Jurnal Nadwa (UIN Walisongo) & 56 per minggu \\
$\mathbf{4}$ & Jurnal Al-Ta'lim (UIN Padang) & 85 per minggu \\
$\mathbf{5}$ & JPI (UIN Yogyakarta) & - \\
$\mathbf{6}$ & Jurnal Tarbiya (UIN Jakarta) & 42 per minggu \\
$\mathbf{7}$ & Jurnal Edukasia (STAIN Kudus) & 73 per minggu \\
$\mathbf{8}$ & Jurnal Arabiyat (UIN Jakarta) & 58 per minggu \\
$\mathbf{9}$ & Jurnal Dinamika Ilmu (IAIN Samarinda) & 82 per minggu \\
\hline
\end{tabular}

Dari segi inovasi, berbagai upaya dilakukan oleh masing-masing pengelola jurnal tersebut dalam rangka peningkatkan kualitas pengelolaan jurnal pendidikan berbasis daring di lingkungan PTKIN. Di bidang prasarana, semua pengelola jurnal sudah dibekali dengan ruang khusus pengelolaan jurnal yang dilengkapi dengan fasilitas internet dan komputer yang memadai. Di bidang kebijakan, Jurnal JPI dalam hal ini kampus UIN Yogyakarta, menerapkan kebijakan prioritas bantuan hibah penelitian untuk pengelola jurnal. Di bidang strategi penjaringan artikel, Jurnal Arabiyat bekerjasama dengan IMLA Indonesia membentuk perkumpulan pengelola jurnal kajian bahasa Arab dalam rangka penjaringan artikel dan pendampingan akreditasi jurnal kajian bahasa Arab di Indonesia. Di bidang strategi peningkatan kunjungan unik, jurnal Edukasia dalam hal ini STAIN Kudus, memberikan tugas kepada semua mahasiswa baru pada masa orientasi untuk meresume artikel-artikel yang ada di laman OJS STAIN Kudus sesuai dengan bidang ilmu yang dipilih. Di bidang penjaringan mitra bestari, jurnal Tarbiya memanfaatkan jejaring tim redaksi lulusan luar negeri untuk mengundang para ahli di sana untuk menjadi mitra bestari.

\section{Simpulan}

Dari 9 (Sembilan) Jurnal Bidang Ilmu Pendidikan di Lingkungan PTKIN yang terakreditasi sebelum tahun 2018, Jurnal Dinamika Ilmu paling banyak dikutip, yaitu sejumlah 251 (dua ratus lima

To cite this document:

Albantani, A. M., \& Arifin, F. (2020), Management of Accredited Scientific Education Journals in State

Islamic Universities. Record and Library Journal, 6(2), 154-165.

Open access under Creative Commons Attribution-Non Commercial-Share A like 4.0 International Licence

(CC-BY-SA) 
puluh satu) kali. Hal ini, sangat wajar karena Dinamika sudah memasuki usia ke 18 (delapan belas) tahun. Sedangkan, Jurnal Edukasia paling sedikit dikutip, yaitu sejumlah 5 (lima) kali. Padahal usia Edukasia memasuki tahun ke 13 (tiga belas). Selain itu, dari ke 9 (sembilan) jurnal tersebut, hanya Jurnal Edukasia yang masih mempertahankan untuk menggunakan full text bahasa Indonesia meski sudah terakreditasi nasional. Sedangkan Jurnal Edusains, Jurnal JPI, Jurnal Tarbiya, dan Jurnal Dinamika Ilmu dengan mantap menggunakan full text bahasa Inggris. Hal tersebut, dilakukan dalam rangka menunjang visi Go International untuk jurnal-jurnalnya.

Sedangkan inovasi pengelolaan jurnal ilmiah bergantung kepada berbagai upaya-upaya yang dilakukan oleh pengelola, serta bergantung kepada kebijakan kampus yang menunjukkan kepedulian terhadap pengelolaan jurnal ilmiah. Pengelolaan Jurnal Pendidikan Islam (UIN SGD Bandung), Jurnal Pendidikan Islam (UIN SUKA Yogyakarta), Edukasia: Jurnal Penelitian Pendidikan Islam (STAIN Kudus), dan Dinamika Ilmu (IAIN Samarinda) memiliki inovasi yang beragam. Namun, kebijakan anggaran yang kurang berpihak pada pengelolaan jurnal di kampus menjadi kendala yang sama-sama dihadapi oleh kesembilan jurnal tersebut.

\section{Referensi}

Anggoro, M.T. (2007). Metode Penelitian. Jakarta: Universitas Terbuka.

Ansor, S. (2017). Studi Meta Analisis Strategi dan Pemanfaatan Jurnal Elektronik (e - journals) untuk Mahasiswa Lulusan Universitas Negeri Malang dalam Upaya Publikasi Ilmiah Bereputasi Internasional. Record and Library Journal, 3(1).

Arikunto, S. (2006). Prosedur Penelitian: Suatu Pendekatan Praktik. Jakarta: Rineka Cipta.

Arikunto, S. (2010). Prosedur Penelitian: Suatu Pendekatan Praktik. Jakarta: Rineka Cipta.

Creswell, J.W. (1998). Qualitative Inquiry and Research Design: Choosing Among Five Traditions.

Thousand Oaks, London dan New Delhi: Sage Publication.

Ditlitabmas. (2014). Pedoman Akreditasi Terbitan Berkala Ilmiah. Jakarta: Direktorat Jenderal Pendidikan Tinggi Kemendikbud RI.

Donim, S. (2002). Menjadi Peneliti Kualitatif. Bandung: Pustaka Setia.

Hariyah. (2016). Tren Penelitian Studi Islam dalam Jurnal Badan Litbang dan Diklat Kemenag RI: Penggunaan Co-Words. Record and Library Journal, 2 (2).

Hariyanto, E. (2016). Qua Vadis The Quality of Online Scientific Journal Publishing in State Islamic Religious University (PTKIN). Khizanah Al-Hikmah, 4 (1).

Kusuma, R.C.D. (2016). Pemanfaatan EZ proxy untuk mengakses jurnal internasional oleh mahasiswa

S2 Ilmu Perpustakaan dan Informasi, Universitas Indonesia. Record and Library Journal, 2(1).

Marzuki. (2005). Metodologi Riset. Yogyakarta: Ekonisia.

Meleong, L.J. (2002). Metode Penelitian Kualitatif. Bandung: Remaja Rosda Karya.

Nashihuddin, W., \& Aulianto, D.R. (2016). Pengelolaan Terbitan Berkala Ilmiah Sesuai Ketentuan Akreditasi: Upaya Menuju Jurnal Trakreditasi Dan Bereputasi Internasional. Jurnal Pustakawan Indonesia, 15 (1-2).

Nazir, M. (1999). Metode Penelitian. Jakarta: Ghalia Indonesia.

Peraturan Direktur Jenderal Pendidikan Tinggi Kemdikbud RI Nomor 1 tahun 2014 tentang Pedoman Akreditasi Terbitan Berkala Ilmiah.

Permenristekdikti Nomor 20 Tahun 2017 tentang Tunjangan Dosen dan Kehormatan Profesor.

Prastowo, A. (2012). Metode Penelitian Kualitatif dalam Perspektif Rancangan Penelitian. Yogyakarta: Ar- Ruzz Media.

Rahmat, P.S. (2009). Penelitian Kualitatif”. Jurnal Equilibrum, 5 (9).

Rosyada, D. (2015). Persiapan Jurnal-jurnal UIN Jakarta menuju terakreditasi nasional dan terindeks internasional bereputasi. Lokakarya Koordinasi Pengelolaan Jurnal UIN Jakarta.

Sya'ban, A. (2005). Teknik Analisis Data Penelitian. Jakarta: UHAMKA.

To cite this document:

Albantani, A. M., \& Arifin, F. (2020), Management of Accredited Scientific Education Journals in State

Islamic Universities. Record and Library Journal, 6(2), 154-165.

Open access under Creative Commons Attribution-Non Commercial-Share A like 4.0 International Licence

(CC-BY-SA) 